\title{
Do parnaso aos trópicos origem e evolução do tribunal do júri
}

\author{
Eduardo Diniz Neto ${ }^{1}$
}

\section{Resumo}

\begin{abstract}
O Tribunal do Júri é, sabidamente, a mais democrática das instituições jurídicas. Como verdadeira homenagem à soberania popular pelo exercício direto da administração da justiça, não é sem razão que sua criação e adoção, contemporaneamente, coincidem com contextos históricos de ruptura liberalizante. Sua gênese, no entanto, remonta, para muitos, à antigüidade. Buscar suas origens mais remotas, passando por sua evolução no tempo e no espaço, até chegar aos contornos atuais do instituto em nosso ordenamento jurídico são os propósitos primordiais deste trabalho, aos quais se alia o auspício de contribuir, ainda que timidamente, para uma melhor compreensão de suas características e sistematização, a despertar, quiçá, proposições para a contínua modernização e aperfeiçoamento do tribunal popular, de modo que continue a consubstanciar efetivo instrumento de realização de justiça.
\end{abstract}

Palavras-Chave: Tribunal do Júri; História; Origem; Evolução.

\section{Introdução}

O presente artigo versa sobre a origem e evolução histórica do tribunal do júri induvidosamente, a mais democrática das instituições jurídicas -, consagrada na maioria dos países, dentre eles o Brasil, cujo direito é haurido da tradição romanística, com o escopo de trazer cabedal arqueológico para identificar os fatores desencadeadores das tendências hoje em voga no nosso ordenamento e, quiçá, despertar o interesse para o desenvolvimento de mecanismos dirigidos à modernização e à conseqüente sobrevivência do tribunal popular.

Para tanto, incursiona-se, num primeiro momento, pelas origens históricas do júri apontadas como universalmente mais remotas e sua evolução, até se concentrar na sua implantação e desenvolvimento em Portugal e no Brasil, de sorte a possibilitar, ademais, a

1 Mestre em Ciências Jurídico-Criminais pela Universidade de Coimbra-Portugal. Promotor de Justiça em Londrina-PR. Professor da Universidade Estadual de Londrina - UEL. Coordenador do Curso de Especialização lato sensu em Direito Penal e Processual Penal da UEL. Professor e membro do Conselho Diretivo da Fundação Escola do Ministério Público do Estado do Paraná - FEMPAR. Professor da Escola da Magistratura do Trabalho - EMATRA/PR. Secretário da coordenação paranaense da Associação Brasileira de Professores de Ciências Penais - ABPCP. 
análise dos modelos que mais proximamente inspiraram a hodierna legislação pátria no que respeita aos caracteres e sistematização do tribunal.

\section{Origem e evolução do júri}

\subsection{Origens remotas}

Não há uma unidade doutrinária absoluta sobre a origem do júri. Há aqueles que defendem, com respeitáveis e robustos argumentos, encontrarem-se os mais remotos antecedentes do Tribunal do Júri na lei mosaica; nos dikastas, na Heliéia (tribunal dito popular) ou no Areópago gregos; no processo penal romano, sob o sistema das quaestiones; nos centeni comites dos primitivos germanos; ou, ainda, na Inglaterra da Idade Média, de onde passou para os Estados Unidos e, depois, de ambos para os continentes europeu e americano. Ressalte-se que tampouco quanto ao aparecimento da instituição do júri considerado em sentido próprio e com os contornos embrionários específicos dos dias atuais - existe uma unanimidade sobre sua origem: para uns autores, o júri teria aparecido na Inglaterra do século XII, sob a forma de "júri de acusação", introduzido por Henrique II após a conquista normanda; para outros, o júri surgiria em França, na época carolíngea, sob a forma de processo inquisitório, composto de homens justos e dignos sob juramento, cuja função era dar conhecimento do que havia ocorrido nos seus distritos aos juízes ambulantes do rei francês, para que este, então, administrasse a justiça² .

Sobre a disparidade de opiniões com respeito à origem do júri já se pronunciou Ruy Barbosa $^{3}$, num globalizado enfoque, com sua peculiar maestria:

Se o Júri, de que já se encontra a prefiguração longínqua nos judices romanos ('Le jugement par de véritables jurés'. Guérin: 'Étude Sur Les Droits et Libert Du Citoyen aux Et. Unis'. Bulletin de La Soc. de Legisl. Comp. 1892, p. 320 n. - Lesser: 'Jury System', c. III), se não nos 'dikastas' gregos e nos 'centeni comites' dos primitivos germanos, imortalizados por Tácito (Tácito: 'De Situ ac Populis Germaniae', XII), autorizando historiadores e entuziastas seus a gabarem-no de medir o curso da civilização ('The development of the jury may justly be said to measure the march of civilization'. Lesser: 'The Historical Development of the Jury System', New York, 1894, p. 14 - '... the jury thus gained ground with advancing civilization, gradually superseding the more ancient and barbarous customs...';

QUEIRÓS, Barros de . Tribunais de Jurados. Portugal Judiciário, n. 1, p. 9, 1976.

BARBOSA, Ruy. O Júri Sob Todos os Aspectos. Textos sobre a Teoria e Prática da Instituição, coligidos e ordenados por Roberto Lyra Filho e Mário César da Silva. Rio de Janeiro: Editora Nacional de Direito, 1950, p. 27-28. 
Macclacklan: Engl. Cycl. III, 26 - 'The jury system is both the cause and proof of civilization and liberty'. Cox: 'Three Decades of Federal Legislation, p. 604), se o Júri, associado, na investigação das suas origens históricas, ora aos teutões, ora aos eslavos, já aos normandos, já aos dinamarqueses (Ellis Stevens: 'Sources of the Constit. of the United States', p. 233-4 - Franqueville: 'Le Système Judiciaire de La Grande Bretagne'. I, p. 490-92), recebeu os primeiros traços de sua forma definitiva no solo britânico, depois da conquista normanda, sob Henrique II, extinguindo-se na França, de onde fôra transplantado nos seus mais grosseiros rudimentos com as Capitulares (Stubbs: 'The Constitutional History of England', v. I, p. 612-15), na média idade inglesa é que ele revestiu a imagem, sob que a era moderna o adotou. Contudo, é contemporâneo o momento da sua culminação jurídica, o período da sua universalidade, a época da generalização dos seus benefícios a tôda parte culta da espécie humana.

Os autores que procuraram evidenciar a origem do júri no Areópago e na Heliéia da Atenas clássica indicam pontos em comum entre essas duas instituições judiciárias gregas e o júri":

O Areópago, encarregado de julgar os crimes de sangue, era guiado pela 'prudência' de um senso comum jurídico. Seus integrantes, antigos arcontes, seguiam apenas os ditames de sua consciência. A Heliéia, por sua vez, era um tribunal popular, integrado por um número significativo de heliastas (de 201 a 2.501), todos cidadãos "optimo jure", que também julgavam, após ouvir a defesa do réu, segundo sua íntima convicção. Parecem elementos bastantes para identificar aqui os contornos mínimos, o princípio ao qual a idéia de justiça popular historicamente se remeteria.

Há autores, entretanto, como Pinto da Rocha ${ }^{5}$, que apontam origem ainda mais remota do Tribunal do Júri, especificamente a partir da lei mosaica, onde se vislumbra a existência de tribunais coletivos e populares, embora sem a complexidade dos gregos, que surgiriam em momento histórico posterior:

É muito além do Capitólio e do Parthenom e não nos Heliastas e Dikastas gregos, como pretende a corrente hellenista, que nós procuraremos a origem da instituição. As leis de Moyses, ainda que subordinando o magistrado ao sacerdote, foram, na antiguidade, as primeiras que interessaram os cidadãos nos julgamentos dos tribunaes. Muito antes, portanto, de, na Grécia antiga, ser chamado o povo para decidir todas as grandes questões judiciárias, em plena praça pública, no exercício da justiça atheniense, antes da constituição desse tribunal, que era composto de cidadãos escolhidos entre os que todos os annos a sorte designava

4 ARAÚJO, Nádia; ALMEIDA, Ricardo R.. O Tribunal do Júri nos Estados Unidos - sua evolução histórica e algumas reflexões sobre seu estado atual. Revista Brasileira de Ciências Criminais, São Paulo, v. 15, p. 201202, 1996.

5 ROCHA, Arthur Pinto da. Primeiro jury antigo. Dissertações (Direito Público), organizadas por Manoel Álvaro de Souza Sá Vianna, por ocasião do Congresso Jurídico Americano, comemorativo do 4 o centenário do descobrimento do Brasil, Rio de Janeiro: Imprensa Nacional, 1904, v. 2, p. 530-531. 
para julgarem collectivamente ou divididos em secções, muito antes da existência desses juízes populares aos quaes, como requisitos eram apenas exigidas a edade de trinta annos, reputação ilibada e quitação plena do thesouro público; muito antes do aparecimento desse tribunal de pares, já o Deuteronomio, o Exodo, o Levitico e os Numeros, na formosa e símplice linguagem do direito mosaico, nos fallam do Tribunal Ordinario, do Conselho dos Anciãos e do Grande Conselho. Na velha legislação mosaica encontramos nós o fundamento e a origem da instituição do jury.

Outros, contudo, consideram que, por reclamar a noção de tribunal popular (determinação do julgamento de pessoa, integrante da comunidade, por seus pares) uma estruturação mínima, por mais rudimentar que seja e, correlatamente, a observância de regras, ainda que também em número reduzido, pré-estabelecidas, só se encontra, assim concebida, em Roma, com a quaestio, órgão colegiado constituído por cidadãos, representantes do populus romano, presidido pelo pretor, e cujas constituição e atribuições - assim como os crimina determinantes da sua competência, e respectivas penas - eram definidos em leges, prévia e regularmente editadas ${ }^{6}$.

Mister se faz, assim, uma breve incursão histórica pelo processo penal romano e as quaestiones perpetuae, à luz das lições de Rogério Lauria Tucci ${ }^{7}$, a começar por rememorar os três sucessivos períodos procedimentais do processo penal romano:

a) o processo comicial, em que pontificaram, inicialmente, o procedimento inquisitório (inquisitio), fundado na cognitio do órgão perseguidor, e caracterizado pela absoluta ausência de formalidades, ou seja, pelo arbítrio sem limites no uso da coertitio; e, sucessivamente, o da anquisitio, no qual a coletividade, ela mesma, fazia-se juíza dos próprios interesses, constituindo-se em órgão judicante, ou, antes, delegando a repressão a agentes estatais, especialmente instituídos para tal fim;

b) o acusatório, em que tiveram lugar as quaestiones perpetuae e se projetou a accusatio, carecedora da figura do acusador particular; e

c) o da cognitio extra ordinem, quando, sobre os tribunais especiais das quaestiones, predominaram os órgãos jurisdicionais constituídos pelo príncipe, e voltou a imperar, com o retorno da cognição espontânea, o procedimento penal ex officio.

6 TUCCI, Rogério Lauria. Tribunal do Júri - Estudo sobre a mais democrática instituição jurídica brasileira. São Paulo: Editora Revista dos Tribunais, 1999,- p. 16 e ss.. Idem. Lineamentos do processo penal romano. São Paulo: Edusp/Bushatsky, 1976, p. 149 e ss..

7 Idem.Tribunal do Júri, p. 16-23. 
Tem-se, assim, que até a época do direito clássico, período do surgimento das quaestiones, não havia ainda sido implantado um verdadeiro sistema penal romano, por desconhecer, antes, os delineamentos do princípio da legalidade ou da reserva legal (nullum crimen nulla poena sine lege).

Tal regramento ${ }^{8}$ adveio, então, da particular necessidade de definição de algumas espécies criminosas carecedoras de uma investigação mais acurada, indispensável com a contínua expansão do Estado romano e a evolução do direito, até mesmo para a garantia do controle sobre os administradores regionais do vasto Império que se formava, tipificando-se, v.g., a concussão do magistrado provincial (crimen repetundarum ou pecuniae repetundae).

A primeira quaestio, espécie de comissão de inquérito, foi instituída pela Lex Calpurnia, de 149 a.C., com o intuito de investigar e julgar (iudicium publicum legitimum) os casos em que algum funcionário estatal tivesse causado prejuízo a provinciano (quaestio repetundis).

Sucederam-lhe várias outras, a ressaltar-se, com Mommsen, Kunkel, Bonfante e Tuozzi, pela sua importância, as quaestiones competentes para conhecer e julgar os crimina de alta traição e de desobediência aos órgãos supremos do Estado (quaestio maiestatis), defraudação da propriedade pública, sacra ou religiosa (quaestio de peculatu et sacrilegio), corrupção eleitoral (quaestio ambitus), assassinato, envenenamento, sentença iníqua de pena capital, magia, falso testemunho ou atentado à segurança pública (quaestio de sicariis et vene ficiis), homicídio de parente próximo (quaestio de parricidis), falsificação de testamento ou de moeda (quaestio de falsis), injúria grave, inclusive a violação da paz doméstica (quaestio de iniuriis), adultério e sedução de donzela de boa fama (quaestio de adulteriis), além dos cometidos com violência (quaestio de vi).

A origem das quaestiones foi, assim, eminentemente política, passando, com o transcorrer do tempo, de transitórias a permanentes, daí a ostentar a determinação de quaestiones perpetuae, constituindo, como já salientado, a primeira espécie de jurisdição penal, propriamente dita, que Roma conheceu.

Por não compreender a quaestio, ao contrário do processo privado (ordo judiciorum privatorum) exigência de qualquer convenção das partes para a ulterior tramitação do

\footnotetext{
8 Para alguns, garantia, e não princípio.

9 MOMMSEM, KUNKEL, BONFANTE, TUOZZI, apud TUCCI, Rogério Lauria, Tribunal do Júri.., op. cit., p. 17-18.
} 
procedimento, bem como pela forma de recrutamento dos participantes do órgão julgador, revestia-se ela, inabalavelmente, de natureza pública. A quaestio era constituída por um corpo de jurados (iudices iuriati), que atuavam, via de regra, sob a presidência de um pretor (quaesitor), sendo todos cidadãos romanos, cujos nomes eram recrutados através de uma lista $^{10}$, designados sem qualquer participação dos sujeitos parciais ou interessados, que só nela interfeririam com a recusa permitida, embora em número limitado, quando da seleção para efetivo julgamento.

Quanto à sua estrutura, portanto, a quaestio era formada por um presidente (praetor vel quesitor) e, no máximo, cinqüenta cidadãos (iudices iuriati), escolhidos, preliminarmente, entre os senadores; posteriormente, com a Lex Sempronia, proposta por Caio Graco (122 a.C.), também entre os cavaleiros; e, finalmente, com a Lex Aurelia (70 a.C.), entre senadores, cavaleiros e tribuni aerarii, uma terça parte de cada ordem.

As listas oficiais eram compostas de cerca de mil nomes de jurados, e estes eram, individualmente, colocados numa urna para serem oportunamente indicados; então, tanto o acusador quanto o acusado podiam recusar os que não os satisfizessem.

Como visto, o presidente (iudex quaestiones) era um magistrado e a ele incumbia examinar, preambularmente, a acusação, decidir sobre a competência, receber o juramento das partes, escolher e convocar os iudices iuriati, presidir as discussões e fazer executar a sentença.

Os jurados não recusados - que, no início, eram indicados (editio) e, com o tempo, passaram a ser sorteados - deviam participar de todo o procedimento, e, no final, pronunciar-se, por meio de votação, pela condenação ou absolvição do acusado, ou, ainda, por um alargamento da instrução.

$\mathrm{O}$ ato inaugural do procedimento acusatório era o correspondente à proposta de acusação, integrante de um processo público, contraditório e oral.

Todo cidadão, em Roma, podia acusar (acusação popular) - Unicuique de populo licebat accusare - exceto os incapazes e os, por qualquer outro motivo, indignos ${ }^{11}$.

10 Segundo Rogério Lauria Tucci, esta lista era elaborada no começo de cada ano, pelo pretor, com o tempo dela extraíram-se, por sorteio, cem nomes, quando da constituição da quaestio. E com a reiectio permitida, reduzia-se a cinqüenta o número de seus iudices iuriati, na ocasião do julgamento.

11 "Eram consideradas incapazes as mulheres, que somente podiam acusar em caso de ofensa aos seus parentes próximos. Também o eram os filii familias, que só podiam postular com o consentimento do pater familias, e os libertos, os quais, entretanto, em situações especiais, eram admitidos a acusar (até mesmo o 
A sustentação da acusação dava-se com o oferecimento do libelo (postulatio, petitio), contendo a delatio criminis, vale dizer, a indicação do crime imputado ao acusado e da lei violada por este, a par da submissão ao juízo com juramento (ius iurandum). Se vários fossem os acusadores, caberia ao presidente escolher, dentre eles, o mais idôneo ou o mais interessado (divinatio), permanecendo os demais como subscriptores.

O acusador, a partir daí, assumiria todos os direitos, deveres e ônus de parte em sentido processual, e, por outro lado, como defensor do interesse público (populus), não podia mais dispor da acusatio formulada, vinculando-se a ela até o final do processo.

Passemos, agora, resumidamente, à análise das peculiaridades do procedimento, pois que, com isso, identificaremos ainda mais semelhanças com a essência do Júri moderno.

Recebida a acusação (nomen recipere), o libelo permanecia guardado no erário público, publicando-se, desde então, o nome do acusado numa tábua, cujo registro só era cancelado após a sua absolvição (subtrahere ex reis).

A seguir, o acusado era citado (edictum per trinundinum) e, ao comparecer, era interrogado sobre a acusação, como formulada. Ao não comparecimento, seus bens eram objeto de inscrição e, um ano depois, confiscados (adnotatio).

Se no interrogatório houvesse confissão, terminava-se o processo, tendo-se o acusado como réu convicto. Caso contrário, negando-se a accusatio, o pretor determinava que o acusador e o acusado voltassem a juízo, em dia desde logo designado (diei dictio), com tempo suficiente à colheita dos elementos de prova; intervalo este que era, ordinariamente, de trinta dias, retraído ou flexibilizado, no entanto, conforme o caso. $\mathrm{O}$ acusador assumia, nesse ínterim, a investigação tendente a roborar a acusação; e o acusado, por seu turno, tinha o direito de acompanhar toda sua atividade, ou querendo, indicar um preposto para controlá-la.

Em juízo, inicialmente eram tomadas as providências já referidas para a composição do órgão julgador (indicação ou sorteio dos nomes dos iudices iurati, observada a recusatio pelas partes). 
Na seqüência, passava-se às alocuções, dada a palavra, por primeiro, ao acusador e, sucessivamente, ao acusado. Num primeiro momento histórico, as orações eram efetivadas pelos próprios interessados; mas, progressivamente, passaram a ser proferidas pelos respectivos patronos constituídos - os oratores ou advocati.

O tempo das intervenções era limitado pelo presidente, admitindo-se a réplica (duplicatio), e, mais recentemente, o prosseguimento em dias sucessivos (comperendinatio).

As provas trazidas eram de três espécies: documental (per tabulas), referente à correspondência privada, aos registros e a outros atos públicos, que podiam constituir objeto de exibição; testemunhal (per testes), tendente à inquirição de pessoas, conhecedoras dos fatos, e que se apresentavam voluntariamente, ou se achavam legalmente obrigadas a depor, não havendo limites quanto ao número de testemunhos ${ }^{12}$; e demais meios de prova (per quaestiones), dentre os quais, em especial, a confissão espontânea ou a obtida mediante tortura.

Em continuidade, consideradas as provas e definidos os pontos norteadores do julgamento, o presidente submetia o caso ao conselho de jurados (mittebat iudices in consilium).

Os iudices iuriati, nos primórdios, votavam oralmente, e depois passaram a fazê-lo supra tabellas: $A$ (absolvo), C (condemno), ou NL (non liquet), esta última significando a remessa a uma instrução mais ampla e acurada. Em decorrência da maioria dos pronunciamentos dos jurados, o quaesitor proclamava o resultado do julgamento, com as fórmulas correspondentes à absolvição (non videtur fecisse), à condenação (iure videtur fecisse), ou ao alargamento da instrução (amplius cognoscendum). Em caso de empate, no sufrágio, absolvia-se o acusado.

Mister se faz salientar, todavia, que a sentença podia ser proferida divorciada do resultado da votação e não ficava sujeita a qualquer espécie de revisão; a não ser a restitutio in integrum, pronunciada por magistrado superior, em casos excepcionais e graves, como a incompetência do tribunal processante, ou a inobservância de garantias fundamentais à defesa do acusado.

12 V. também, sobre todo o desenrolar do procedimento, MALINVERNI, Alessandro. Lineamenti di storia Del diritto romano. Turim: G. Giapichelli, 1972, p. 3-5. 
Finalmente, digna de destaque era a peculiar via que se tomava em caso de absolvição, quando então se instaurava processo contra o acusador, que era punido extra ordinem, segundo o senatusconsulto Turpilliano.

Paralelamente ao processo acusatório romano, os povos bárbaros, especialmente os germânicos, desenvolveram tribunais vehmicos, que se caracterizavam - não obstante a flagrante distância que propositalmente o direito germânico procurava manter das instituições romanas e cristãs - pela popularização dos juízos. Esses tribunais, cuja origem é igualmente remota, existiram essencialmente na Westphalia, até o século XVI e eram, contudo, secretos, bem como desconhecidos os juízes - homens livres que exerciam grande influência e "dominavam todas as classes com poderes ilimitados" - em número de cem, os quais atuavam sob o comando de um Príncipe, designado para determinado cantão para administrar a justiça ${ }^{13}$. E os autores asseveram, ainda, que na gênese dessa organização, os julgamentos eram efetuados diretamente pelo povo ${ }^{14}$.

Dentre os povos chamados bárbaros, os francos também tiveram seu tribunal popular, o mall ou placitum, composto por homens livres ou notáveis - os rachimburgos ou boni homines in malbergo sedentes ${ }^{15}$.

Com a invasão do Império Romano pelos bárbaros, e conseqüente domínio do direito destes sobre o subjugado, em cada cidade ou burgo estabeleceu-se um tribunal popular composto de homens livres, denominados coniuratores ou compurgatores, ao qual incumbia a verificação existencial do fato criminoso e apuração da respectiva autoria e após, as atuações acusatória e defensiva - do julgamento da causa, sob a presidência do Conde ${ }^{16}$, e em consonância com a lei comum.

Contudo, acentuadamente em virtude da dificuldade de comunicação entre os burgos, abusos, escândalos, corrupção dos julgadores, os reis foram levados a substituíremnos por cidadãos idôneos e instruídos, os escabinos, rigorosamente

13 ROCHA, Arthur Pinto da. Primeiro jury antigo. Op cit., p. 565.

14 "E é certo, ainda, que foram precedidos, nos primeiros tempos, pelo julgamento popular, isto é, do próprio povo, sem qualquer representatividade, realizado no Campo de Março, ou Campo de Maio, e relativo às denominadas causas capitais. Mas, paulatinamente, os plaids (assembléias públicas julgadoras dos processos), especialmente os provinciais, passaram a exercer a jurisdição criminal; e as audiências do júri eram presididas pelo graf, que, entretanto, não participava das votações" - TUCCl, Rogério Lauria. Tribunal do Júri, Op. cit., p. 25-26.

15 ROCHA, Arthur Pinto da. Primeiro jury antigo. Op. cit., p. 566.

16 Ao qual eram atribuídos, tão somente, o relato dos fatos, apontando as questões subjacentes; a tomada dos votos e julgamento, sem participação na votação. 
selecionados pelo Conde, o mesmo tendo sucedido, no momento histórico a seguir - o feudalismo - na medida em que, inicialmente a intervenção real era reduzida à invocação da autoridade régia, especialmente quando da apreciação final da causa, cabendo aos cidadãos - senhores de feudos, vassalos ou feudatários - a prerrogativa do julgamento de seus pares, sistema que, pelos mesmos graves motivos acima consignados, desencadeou a paulatina concentração da justiça nas mãos do Conde e do senhor feudal, perdendo o tribunal popular as características que lhe davam contornos assemelhados aos da instituição do júri ${ }^{17}$.

Qualquer que seja a origem do júri, foi na Inglaterra, onde ele se encontra desde tempos remotíssimos, que o instituto alcançou, após lenta e gradual evolução, integrado que foi ao sistema legal desde as primeiras constituições ${ }^{18}$, o relevo e pujança que modernamente ainda se observa, tanto que a influência e tradição do direito anglo-saxão com respeito ao mesmo ultrapassa os territórios de suas ex-colônias, irradiando-se pela Europa continental e América.

Não se deve olvidar, entretanto, como bem traduz Barros de Queirós ${ }^{19}$, que o aparecimento do júri, mesmo em Inglaterra, está, em grande medida, ligado ao problema da prova de capital importância em Processo Penal. E sustenta:

Tal como em França, a princípio, o juiz inglês era um juiz itinerante, sem conhecimento das particularidades locais, o que o levou a recorrer ás gentes do local e aos vizinhos do acusado para melhor conhecer as questões de facto; se o juiz considerasse o acusado culpado, este teria que se submeter ao julgamento por Deus que poderia consistir na prova de água quente ou fria. [...] Este tipo de julgamento foi abolido em 1215, no Concílio de Latrão. [...] Em Inglaterra, uma vez que respeitavam o processo per acusationem, levou-os a que enviassem o acusado, que não confessasse, a um júri aumentado, formando o júri de julgamento. [...] Esta divisão do júri em dois, sendo um de acusação e o outro de julgamento, penetrou fortemente na prática judiciária inglesa de então e veio a ser consagrada lei de 1352.

17 A esse respeito, pondera Pinto da Rocha, O jury e a sua evolução, Rio de Janeiro: Leite Ribeiro e Maurillo, 1919, p. 55: “... o julgamento pelos pares não equivale de modo nenhum ao julgamento pelos jurados. 0 tribunal dos pares, que caracterizou o systema judiciario das sociedades feudaes, não tem a mesma significação do Jury. Aquelle estabelece o julgamento por meio de categorias, pressupõe a desegualdade politica como fundamento da organização social: este repelle a idéia de classe e funda-se na máxima igualdade politica."

18 DAUSTE, apud MACIEIRA, António. Do Júri Criminal. Imprensa Nacional, Lisboa, 1914, p. 6, nota 1: “...dá-nos uma relação, por ordem cronológica, de todos os monumentos constitucionais da Inglaterra, o primeiro dos quais é de 1100. Parece pela redacção do artigo 29.o da grande carta de Henrique III (1225) que o julgamento dos homens livres pelos seus pares já era uma garantia constitucional anterior."

126

Revista de Direito PúBlico, LondrinA, V. 1, N. 3, P. 117-138, SET./DEZ. 2006. 
Com efeito, com a conquista normanda das ilhas britânicas é que ali se instalou e enfatizou a modalidade de atuação judicial popular, por aqueles haurida dos romanos, ainda que de maneira rude, imperfeita, recorrendo-se, inicialmente, à prova per inquisitionem, com emprego de medidas de constrangimento e especialmente da tortura judiciária tendente à obtenção da confissão. A essa altura, os jurados eram, segundo tudo indica, os compurgatores, que implantavam o júri nas terras conquistadas, adequando-o aos costumes e tradições ingleses de maneira que daí originou peculiar órgão julgador diferenciado, dito de caráter misto.

Progressivamente, o juiz será levado a confiar aos jurados as soluções das questões de fato (tanto relativas a matérias penais, quanto civis), submetendo-se o magistrado ao seu próprio desiderato, pois que são eles considerados os guardiões do sentimento popular e os garantes da independência e imparcialidade da sentença. A acusação não poderá ser feita sem a sua concordância, e a culpabilidade não poderá ser declarada senão pelos juízes de fato, escolhidos dentre listas elaboradas nas paróquias.

Com essa destinação, aliás, já no século $X$ da Era Cristã, o júri era composto por vinte e quatro pessoas, escolhidos entre os vizinhos do acusado e os moradores do lugar em que tivesse sido cometida a infração penal, permitida a recusa, tanto à acusação como à defesa. Nesta fase, no entanto, o júri era ao mesmo tempo "júri de acusação" e "júri de julgamento", pois apresentava-se como um conjunto de pessoas que testemunhavam em nome da comunidade, e cujo veredicto repousava no conhecimento próprio do fato, assim como do acusado (sua personalidade, vida pregressa, etc. $)^{20}$.

Não são da mesma época, portanto, o grande e o pequeno júri, nem a função primitiva deles é aquela cujo exercício desenvolveu-se até chegar aos dias atuais.

Segundo António Macieira ${ }^{21}$, o grande júri parece filiar-se no grupo de homens que, como inquisidores, e daí o seu nome recognitors, os antigos reis normandos nomeavam por todo o país, sob o juramento de dizerem a verdade, para os informarem principalmente do modo como eram respeitados os seus direitos e privilégios, e porventura algumas vezes os da igreja e particulares, sendo esse indiciariamente o germe dos grand jorors em processo criminal.

20 TUCCI, Rogério Lauria. Tribunal do Júri., Op. cit., p. 28.
21 MACIEIRA, António. Do juri criminal. Op. cit.., p. 6-9. 
Escolhidos dentre homens bons, os recognitors forneciam ao magistrado do inquérito os fatos que verificavam, o qual, por seu turno, os relatava aos soberanos, exercendo aqueles, na verdade, a função de testemunhas. Fazendo-se necessária, na primeira fase, a confirmação do que era informado por aqueles jurados, os soberanos nomeavam então outros jurados, em menor número, que revisavam o inquérito inicial.

Nesse período, de cunho teológico e bárbaro, os recognitors bastavam para a justiça criminal, pois através da prova pela água e pelo fogo não se sentia a necessidade de outro sistema.

Os registros mais antigos deste período dos inquiridores remontam a 1166, quando o tribunal de Clarendon ordenou que se constituíssem em todos os condados comissões de homens bons e juramentados que informassem quem, suspeito de crimes, devia ser submetido àqueles julgamentos de Deus. Em 1194, o tribunal de Northampton indicou qual o modo de nomeação dos recognitors.

Como visto, o Grande Concílio de Latrão, reunido em Novembro de 1215, por convocação do papa Inocêncio III, proíbe aqueles meios bárbaros e cruéis de provas judiciárias, aproveitando-se o espírito religioso dos antigos habitantes da Inglaterra do velho sistema de reverificação dos inquéritos feitos pelos recognitors, passando a constituir-se o pequeno júri como decisório da prova do grande júri. Os primeiros recognitors passam, então, a julgadores de indiciação ou de acusação e os segundos julgadores assumem função de reverificação mais apurada da sentença. Qualquer deles não são meros informadores, mas sim julgadores independentes a quem a liberdade individual é entregue, passando a ter o júri, a partir de então, permanente inclusão como garantia individual nos diplomas de caráter constitucional.

Acrescente-se que, com o transcorrer do tempo, e pelo menos a partir do século XVII, o júri britânico passou a ser composto por doze cavaleiros, número este, para alguns, dito místico, pela recordação do número de apóstolos de Cristo ${ }^{22}$.

Apesar dos inúmeros statutes, rights, customs e practices a que o instituto tem sido subordinado desde então, inclusive com a edição de leis gerais sobre sua organização e funcionamento, o júri britânico não deixa de ser ainda hoje orientado predominantemente pela prática e pelos costumes.

22 TUCCI, Rogério Lauria. Tribunal do Júri., Op cit., p. 28. 
É assim que o júri inglês sobreviveu como uma instituição democrática, apesar de todas as vicissitudes políticas, mesmo durante a monarquia absoluta, embora haja sofrido perseguições como a da condenação do jurado Buschel, sob o reinado de Carlos II, por ter votado a absolvição no processo Peén e Mead ${ }^{23}$.

O júri inglês, com essas características e antes mesmo de se irradiar no continente europeu, estabeleceu-se na América do Norte, tendo sido formalmente consagrado, como anota Ruy Barbosa ${ }^{24}$, na Carta Régia outorgada ao primeiro grupo de imigrantes incumbido da ocupação do novo território, os colonos de Plymouth, em 1629. Assim, ainda no século XVII e antes mesmo da independência, o processo do júri foi ali generalizadamente adotado, abrangendo o "julgamento geral de todas as causas".

Consagrado pela Constituição de 1789, e igualmente - embora não fosse, como é até os dias atuais, sua organização idêntica em todos eles - nos diversos Estados federados, o primitivo tribunal teve uma evolução significativa, sendo mesmo por vezes substituído pelo juiz, sem júri

Prezavam o direito ao julgamento por tribunais de jurados como um direito fundamental do cidadão, um direito ingênito aos americanos, "o seu patrimônio hereditário", "a parte mais preciosa da herança inglesa", tanto que, quando se separaram da mãe pátria, um dos agravos mais trovejados pelo Congresso, como afronta suficiente para justificar a revolta, foi o de que o governo de Jorge III os privara, em muitos casos, do benefício do júrii ${ }^{25}$. São palavras, aliás, da Declaração de Independência: “... for depriving us in many cases of the benefit of trial by jury".

Os lineamentos básicos do júri inglês transplantaram-se, assim, para o júri americano, com todas as formalidades revestidas de publicidade, oralidade e contraditoriedade real.

Os tribunais de jurados, desde então, são formados por um único juiz e por doze jurados. Tal qual na Inglaterra, o júri decide das questões de fato, da culpabilidade; o juiz decide, fixa a pena. No momento da votação, assumem o debate e a deliberação caráter sigiloso. Assim que atingido o resultado necessariamente unânime, o chefe do júri faz

23 GLASSON E., apud MACIEIRA, António. Do júri criminal. Op. cit., p. 9.

24 PIRES, Homero. Comentários à Constituição Federal Brasileira. São Paulo: Saraiva, 1934, v. 6, p. 120-1.

25 BARBOSA, Ruy. O júri sob todos os aspectos. Op. cit., p. 30. 
publicamente a leitura do veredicto na sala própria do tribunal e na presença do acusado. Se a unanimidade não for alcançada, o júri é dissolvido e convocado um novo.

A concluir esta parte do estudo evolutivo da instituição do júri, adentraremos o solo francês ao tempo da Revolução, ao passo em que os seus ideais iluministas influenciaram e de fato afetaram significativamente a organização judiciária do país.

Bebendo na fonte inglesa e na fonte americana a idéia das garantias individuais, a revolução francesa assimilou a grande instituição tutelar da justiça criminal $^{26}$ (grifo nosso).

Logo a seguir à edição, pela Assembléia Constituinte, dos decretos de 8 de Outubro e 3 de Novembro de 1789, e de 24 de Março de 1790, através dos quais deliberou-se que a justiça seria totalmente remodelada, a instituição do júri foi estabelecida em França pelos Estados Gerais e fixada definitivamente para o crime pelo decreto de 30 de Abril de 1790, tendo sido admitida por voto quase unânime. "Le résultat état prévu. Les homes d’Ètat les publicistes, les magistrats, eux-mêmes, voyaient, á cette èpoque, dans l'institution du jury un remède souverein aux abus et á l'arbitraire de l'ancien régime"27.

Assim é que, contrapondo-se ao atroz passado - aquando da onipotência judicial, não sujeita a devido processo legal, nem, tampouco, a prévias e definidas penas, que eram literalmente fabricadas ao alvedrio do magistrado, características do hediondo processo inquisitorial em voga, sem audiência nem defesa do acusado, a imperar a tortura mais cruel como forma de obtenção da confissão, a rainha das provas, tudo em nome da doutrina da expiação, que, atrelando o sentimento da justiça ao sentimento religioso, considerava o crime uma ofensa dirigida diretamente a Deus, daí resultando que a "fabricação" do remorso era indispensável - a França, em princípio influenciada pelo modelo inglês, mas sem olvidar suas leis e costumes da época bárbara e feudal, adotando, por primeiro, os princípios da legalidade e anterioridade da lei penal, instituiu o júri, desdobrando a ação de julgar, impondo obstáculos ao arbítrio, conferindo-lhe, entretanto, caráter eminentemente político, implicativo de modificações determinadas pelas variações experimentadas em eventos dessa mesma natureza.

A Constituição de 3 de Setembro de 1791 concretizou o princípio basilar do júri no decreto de 30 de Abril de 1790: “Aprés l'accusation admise, le fait sera reconnu et declaré

26 BARBOSA, Ruy. O Júri sob todos os aspectos. Op. cit., p. 34.

27 GLASSON, E. Apud MACIEIRA, António. Do juri criminal. Op. cit., p. 13. 
par les jurés, l'application de la loi sera faite par les juges". E a lei de organização judiciária de 16-29 de Setembro de 1791 regulou o funcionamento do júri sob a forma de júri de acusação e de sentença.

Regia o instituto, então, a publicidade dos debates - quer orais, quer escritos - a par da determinação de que o júri funcionaria nas causas criminais. Estabeleceu-se, outrossim, a necessidade de ser eleitor para o cidadão alistar-se como jurado, privando do direito de sufrágio a qualquer função pública, por dois anos, quem não se inscrevesse na lista dos jurados.

O processo penal passou a compor-se de três fases, a saber: a) instrução preparatória; b) júri de acusação, formado por oito membros, sorteados de uma lista de duzentos cidadãos; e c) debates e júri de julgamento, formado por doze membros, sorteados de uma lista de duzentos cidadãos, com direito de recusa de vinte, pelas partes, isto é, tanto pelo acusador como pelo acusado.

A proclamação do voto era individual e em voz alta, emitindo-o, cada jurado, sem necessidade de explicitá-lo, pelo fato de decidir somente de acordo com a sua consciência, bem como se instituiu o resultado por maioria, no caso de condenação, exigindose, para tanto, nove votos; ao contrário, assim, da exigida unanimidade da Inglaterra.

Desde então, e sempre conforme as tendências políticas predominantes, dezenas de leis atinentes a modificar a organização e atribuições do júri foram editadas, sem contudo, apesar das muitas e acerbas censuras que tem sofrido, ter deixado de existir naquele país.

Às infrações ou crimes considerados mais graves sempre adstringiu-se a competência do tribunal do júri.

Com o decurso do tempo, os jurados passaram a colaborar com os magistrados, tanto no exame das questões relativas à culpa, como no exame daquelas que respeitam à aplicação da pena, deixando de se limitar, como visto, à decisão sobre a matéria de fato. 0 "júri de julgamento" passou a ser composto por nove jurados, não recusados pelas partes dentre 23 a 27 que compõem cada lista de sessão; exige-se, outrossim, a maioria absoluta, isto é, de ao menos sete votos nas deliberações.

O resultado dos diferentes votos é mencionado na folha dos quesitos, servindo de base à decisão ou ao acórdão. 


\subsection{0 júri em Portugal}

Terminamos propositalmente o retrospecto histórico do júri por França, não só porque corresponde, dentre os tradicionais sistemas do júri analisados, ao cronologicamente menos remoto, mas também, e principalmente, porque foi aquele que diretamente influenciou a criação e instituição do tribunal de jurados em Portugal ${ }^{28}$ e, conseqüentemente, nos primórdios do Brasil como nação independente. Na esteira de Macieira e Martins de Almeida, diz-se, efetivamente, que foi da França que Portugal "importou" a participação do povo na administração da Justiça através do júri, em que pese, no entanto, não derivar necessariamente dos princípios democráticos, mas antes de razões de política criminal.

À legislação cruel que as Ordenações Filipinas copiaram das Afonsinas e Manuelinas, sob influência do direito germânico, canônico, romano, bem como do direito das "Siete Partidas" de Afonso X de Espanha - atribuindo à pena função divina e expiatória, arraigada ao terror e ao despotismo, violadores dos direitos individuais e dos da propriedade - vieram contrapor-se as idéias liberais da revolução de 1820, reflexo daquelas norteadoras da revolução francesa de 1789 , e que, por isso, proclamou os princípios do título I da Constituição de 1822, entre os quais aquele do art. 40.o: “Toda a pena deve ser proporcionada ao delito; e nenhuma passará da pessoa do delinqúente. Fica abolida a tortura, a confiscação de bens, a infâmia, os açoites, o baraço e o pregão, a marca de ferro quente e todas as mais penas cruéis e infamantes".

Em decorrência, a mesma razão que orientou o legislador francês a adotar o júri foi a que inspirou o legislador português, estabelecendo-se os juízes de fato como elemento componente do poder judicial independente, a despeito da falta de preparo dos jurados, muitas vezes rendidos ante a pressão das forças econômicas e dos interesses políticos, "transformando-se em instrumentos de sectarismo e de vingança".

Assim, não sem prévia e larga discussão, a Constituição Portuguesa de 23 de Setembro de 1822, relativamente à norma basilar do júri, consagrou: "Haverá juízes de facto assim nas causas crimes como nas cíveis, nos casos e pelo modo que os códigos

28 MACIEIRA, António. Do juri criminal. Op. cit., p. 23 e ss.; ALMEIDA, Dario Martins de. O Livro do Jurado. Coimbra: Livraria Almedina, 1977, p. 143-6; QUEIRÓS, Barros de. Tribunais de Jurados. Op. cit., p. 10. 
determinarem"(art. 177으). Como veremos, a partir de então só a Constituição de 1933 não previu o júri.

A Carta Constitucional de 1826 recepcionou, no seu art. 118.ำ o princípio e forma do art. 177.o da Constituição de 1822, substituindo apenas a locução "juízes de facto", declarando, outrossim, que "os jurados se pronunciam sôbre o facto e os juízes aplicam a lei" ${ }^{29}$.

Regulamentando o júri comum, Mousinho da Silveira, acompanhado de Silva Carvalho e outros, baixou o Decreto n. 24 de 16 de Maio de 1832, diploma publicado juntamente com a reforma da Fazenda e da Administração.

Procurou-se conceder autonomia à função judicial, confundida, até então, com as funções do Executivo, dividindo Portugal em Círculos Judiciais, depois chamados distritos de Relação, subdivididos, por sua vez, em Comarcas. "Tudo se passava ainda na Ilha Terceira, onde os liberais se preparavam para vir enfrentar, no continente, as tropas dos absolutistas de D. Miguel".

Mas foi sobretudo com a Novíssima Reforma Judiciária de Costa Cabral, diploma instituído pelo decreto de 21 de Maio de 1841, sob o reinado de D. Maria II, que o júri penetrou na prática da organização judiciária, consolidando-se, apesar das várias alterações que viria a sofrer nesse interregno, até 1927.

Constituía-se então num júri duplo: o "júri de pronúncia" e o "júri de sentença”. Ao primeiro, segundo a lei, cabia "declarar se deve ter efeito completo de pronúncia o despacho do Juiz e se tem lugar a acusação"; o segundo intervinha " para declarar se está ou não provado o facto controvertido, ou o crime pelo qual o réu for acusado". Compunham-se, um e outro, cada qual de 12 a 9 jurados, decidindo, como visto, sobre matéria de fato. Aplicar o direito era tarefa do juiz.

Havia um júri especial para os abusos de liberdade de imprensa (art. 174.ํ).

A decisão dos jurados, em qualquer das fases (pronúncia ou sentença penal), exigia uma votação < unânime de dois terços >>, podendo o júri fixar, ainda, reconhecido e declarado o direito a perdas e danos, o seu respectivo quantum (art. 1166.ㅇ).

29 Palavras copiadas de Benjamin Constant: "Les jurés prononcient sur le fait: Les juges apliquent la loi". Apud LOPES PRAÇA. Estudo sôbre a Carta Constitucional de 1826 e Acto Adicional de 1852. [S.I.], [s.n.], 1879, pt. 2. 
Os jurados, sob juramento solene desde o início da audiência (art. 1130.), durante a deliberação, ficavam incomunicáveis e não era permitido fornecer-lhes alimento.

Ao longo dos anos, profundas modificações foram introduzidas no sistema pertinente ao júri, coincidindo seu declínio com a ascensão de governos autoritários.

Em 1901, foi promulgada uma lei que retirava ao julgamento do júri determinadas categorias de crimes e os cometia a um tribunal coletivo, numa clara alusão à pretensa incapacidade do tribunal de jurados para bem administrar a Justiça.

Em 1910, imediatamente a seguir à proclamação e à implantação da República, sopravam novamente os ventos dos ideais liberais, reerguendo-se o júri como garantia constitucional de primeira grandeza.

Pelos decretos n. 10.809, de 29 de Maio de 1925, e 12.405, de 01 de Outubro de 1.926, foram introduzidos, respectivamente, o princípio da maioria absoluta ou unanimidade nas votações e a preferência de maiores habilitações literárias na escolha dos jurados.

Mas o declínio da intervenção do júri, acentuadamente em matéria criminal, teve seu passo decisivo com os decretos $n$. o 13.136, de 14 de Fevereiro de 1927 e $n . .913 .255$, de 9 de Março de 1927, porquanto os crimes a que correspondia pena mais gravosa passaram a ser julgados por um Tribunal Coletivo, composto por três juízes de carreira, advindo daí perigosa desconfiança e descrédito quanto às decisões, claramente influenciadas pelos detentores do poder.

No mesmo palmilhar, o primeiro Estatuto Judiciário, aprovado pelo Decreto $\mathrm{n}$. 13.809, de 22 de Junho de 1927, mas substituído, logo após, por outro aprovado pelo Decreto n. 15.344, de 12 de Abril de 1928; O Código de Processo Penal aprovado pelo Decreto n. 15.396, de 19 de Abril de 1928; o Código de Processo Penal de 15 de Fevereiro de 1929; e o Estatuto Judiciário de 23 de Fevereiro de 1944.

Foi definitivamente abolido através da publicação do Estatuto Judiciário de 1962.

Com a Revolução de 25 de Abril de 1974, como tradicionalmente ocorre nos períodos de ruptura liberalizante, voltou à tona a temática do júri. Um ano depois, foi instituído pelo Decreto-Lei 605/75, de 3 de Novembro $^{30}$, adotando composição mista entre

30 O Decreto-Lei n. 605/75, no seu preâmbulo, justificou: << a instituição do júri impõe-se como postulado da ordem democrática instaurada pelo Movimento das Forças Armadas. Na verdade, só os regimes totalitários poderão recear a intervenção dos representantes do povo, base e alicerce de toda a ordem democrática, no 
juízes togados e jurados populares, fórmula consagrada com o advento da Constituição de 1976.

A partir de então, a competência e a estrutura do tribunal do júri têm sofrido substanciais alterações, sumariamente assinaladas a seguir, conforme exposição de Germano Marques da Silva ${ }^{31}$ :

O DL n.o 605/75 atribuiu ao júri competência para o julgamento dos processos de querela (crimes punidos com pena maior - em regra superior a três anos de prisão), quando a sua intervenção fosse requerida pelo MP, pelo assistente ou pelo arguido.

O júri conhecia da matéria de facto e fixava a pena a aplicar. O tribunal do júri era então composto pelos três juízes que constituíam o tribunal colectivo e por oito jurados efectivos e dois suplentes. /.../ Já a Lei Orgânica dos Tribunais Judiciais, de 6 de Dezembro de 1977 (Lei n. 82/77), mantendo a competência do júri para o julgamento dos crimes a que correspondesse processo de querela, dispunha que "o júri intervém apenas no julgamento da matéria de facto". /.../ O CPP/87 atribuiu ao júri competência para julgar os crimes previstos no tít. III e no cap. I do tít. V do livro II do Código Penal, nos termos já referidos, e os que respeitem a crimes a que seja abstractamente aplicável a pena de prisão superior a oito anos e a Lei n.으 24/90, de 4 de Agosto, excepcionou da competência definida pelo CPP/87 os crimes de terrorismo. Entretanto, o DL n.o 387-A/87, de 29 de Dezembro (tribunal do júri), veio estabelecer a composição deste tribunal que passou a ser constituído pelos três juízes do colectivo e por quatro jurados efectivos e quatro suplentes e sobre a competência funcional do júri que passou a intervir "na decisão das questões da culpabilidade e da determinação da sanção".

\subsection{0 júri no Brasil}

O júri foi criado, no Brasil, pela Lei de 18 de junho de 1822, com a competência restrita aos delitos de imprensa ${ }^{32}$, como reflexo da onda liberalizante que então varreu sua outrora metrópole.

Era composto por vinte e quatro juízes de fato, cidadãos selecionados "dentre os homens bons, honrados, inteligentes e patriotas", e do seu pronunciamento cabia apelação para o Príncipe.

Com a proclamação da independência em Setembro de 1822 e outorga da Constituição do Império de 25 de Março de 1824, foi elevado à categoria de ramo do Poder

julgamento dos arguidos. [...] As críticas que normalmente se fazem ao júri bem se podem afastar desde que ele seja composto, tal como sucede em França, por juízes togados e jurados populares $>$. SILVA, Germano Marques da. Curso de Processo Penal, Lisboa: Verbo, 1994, v. 1, p. 159-60.

32 MARQUES José Frederico. O Júri no Direito Brasileiro. 2. ed. São Paulo: Saraiva, 1955, p. 49; WHITACKER, Firmino. O Júri. 6. ed. São Paulo: Livraria Acadêmica/Saraiva, 1930, p. 8 e 9; OLIVEIRA FILHO, Cândido. $A$ Reforma do Júri. Rio de Janeiro [s.n.], 1932, p. 9-10; e BARBOSA, Ruy. O Júri sob todos os aspectos. Op. cit.., p. 47 e ss. 
Judiciário (art. 151), independente, ganhando atribuições amplíssimas, "superiores ao grau de desenvolvimento da nação que se constituía", passando a ser composto de juízes e jurados, cabendo a estes se pronunciarem sobre os fatos e àqueles a aplicação das leis.

Ordenando-o especificamente, a Lei de 20 de Setembro de 1830 instituiu o Júri de Acusação e o Júri de Julgação. E o Código de Processo Criminal do Império, de 29 de Novembro de 1832, no mesmo diapasão liberal das leis inglesas, norte-americanas e francesas, deu-lhe, outrossim, demasiado amplas atribuições, que mereceram, não sem razão, exaltadas críticas dos mais renomados analistas de então.

Pelo Código, o Júri de Acusação, dito conselho de jurados, era composto de vinte e três membros; o Júri de Sentença, por doze membros, escolhidos dentre eleitores de "reconhecido bom senso e probidade", com óbvias ressalvas, v.g., ocupantes de cargos políticos.

A Lei 261, de 3 de Dezembro de 1841, e o respectivo Regulamento 120, de 31 de Janeiro de 1842; seguidos pela Lei 522, de 02 de Julho de 1850, e seu Regulamento 707, de 09 de Outubro de 1850; a Lei 2.033, de 23 de Setembro de 1871, regulamentada pelo Decreto 4.992, de 03 de Janeiro de 1872, introduziram modificações significativas na organização judiciária, e também no júri, consagrando reações aos preceitos liberais do antigo Código, extinguindo-se, v.g., o Júri de Acusação, incumbindo da formação da culpa e da sentença de pronúncia autoridades policiais e juízes municipais.

Proclamada a República em 1889, discutiu-se veementemente, no plenário da Constituinte, sua supressão. Porém, o Decreto 848, de 11 de Outubro de 1890, organizando a Justiça Federal, criou o júri federal. E a primeira Constituição republicana, promulgada em 24 de Fevereiro de 1891, em seu art. 72, § 31, assim determinou: “É mantida a instituição do júri".

A partir de então, praticamente todas as constituições brasileiras dispuseram igualmente sobre o júri (art. 72, da de 16 de Julho de 1.934; art. 141, § 28, da de 16 de Setembro de 1946; art. 150, § 18, da de 24 de janeiro de 1967; art. 153, § 18, da emenda Constitucional 1, de 17 de Outubro de 1969; e art. 50, XXXVIII, da de 05 de Outubro de 1988). Praticamente, porque, não obstante a Carta Magna autoritária de 10 de Novembro de 1937 nada ter dito sobre o júri, em 5 de Janeiro de 1938 era promulgado o Decreto-Lei n.o 167, "regulando a instituição do júri", e o Ministro da Justiça Francisco Campos, na exposição 
de motivos que acompanhava o diploma legal, afirmou a subsistência do tribunal popular, por estar compreendido no preceito genérico do art. 183 da Constituição, que declarava em vigor, enquanto não revogadas, as leis que, explícita ou implicitamente, não contrariassem as disposições da Constituição ${ }^{33}$.

Em 1941, entrou em vigor o novo Código de Processo Penal brasileiro (Decreto-Lei n. .3 .689 , de 3 de Outubro de 1941), que regula, até os dias atuais, o processo dos crimes de competência do júri nos arts. 406 a 497. Anote-se que, antes disso, subsistiam códigos processuais penais dos Estados da Federação, igualmente contemplando o júri, além de leis extravagantes como as relativas aos crimes de imprensa e contra a economia popular.

Finalmente, o inciso XXXVIII do art. 5o da vigente Constituição Federal, estabelece: "É reconhecida a instituição do júri, com a organização que lhe der a lei, assegurados: a) a plenitude de defesa; $b$ ) o sigilo das votações; $c$ ) a soberania dos veredictos; $d$ ) a competência para o julgamento dos crimes dolosos contra a vida", lembrando que se insere, e assim é vertido do texto constitucional, no contexto das garantias fundamentais do cidadão, e não meramente como órgão constitutivo do Poder Judiciário, a exemplo da grande maioria dos ordenamentos jurídicos que o contemplam mundo afora.

\section{Conclusão}

Em conclusão, constata-se que a secular instituição do júri evoluiu historicamente a ponto de se conformar com os clássicos ideais humanistas e democráticos, e foi tão arraigadamente recepcionada no nosso país, a despeito de sua tímida competência ao início, que hoje é impensável - sem embargo de naturais imperfeições e críticas delas decorrentes , sua abolição de nossa praxis forense.

O alvo, ao nosso tempo, portanto, é a modernização e o aperfeiçoamento do júri, de modo que sempre consubstancie efetivo instrumento de promoção de justiça através da participação popular na administração do poder jurisdicional do Estado, a concretizar a célebre proposição de Heródoto: "pensar o passado para compreender o presente e preparar o futuro".

33 MARQUES, José Frederico. O Júri no Direito Brasileiro. Op. cit., p. 58. 


\section{Referências}

ALMEIDA, Dario Martins de. O Livro do Jurado. Coimbra: Livraria Almedina, 1977.

ARAÚJO, Nádia; ALMEIDA, Ricardo R. O Tribunal do Júri nos Estados Unidos - sua evolução histórica e algumas reflexões sobre seu estado atual. Revista Brasileira de Ciências Criminais, São Paulo, v. 15, 1996.

BARBOSA, Ruy. O Júri Sob Todos os Aspectos. Textos sobre a Teoria e Prática da Instituição, coligidos e ordenados por Roberto Lyra Filho e Mário César da Silva. Rio de Janeiro: Editora Nacional de Direito, 1950.

LOPES PRAÇA. Estudo sôbre a Carta Constitucional de 1826 e Acto Adicional de 1852. [S.I.], [s.n.], 1879, pt. 2.

MACIEIRA, António. Do Júri Criminal. Lisboa: Imprensa Nacional, 1914.

MALINVERNI, Alessandro. Lineamenti di storia del diritto romano. Turim: G. Giapichelli, 1972.

MARQUES José Frederico. O Júri no Direito Brasileiro. 2. ed. São Paulo: Saraiva, 1955.

OLIVEIRA FILHO, Cândido. A Reforma do Júri. Rio de Janeiro [s.n.], 1932.

PIRES, Homero. Comentários à Constituição Federal Brasileira. São Paulo: Saraiva, 1934. v. 6.

QUEIRÓS, Barros de. Tribunais de Jurados. Portugal Judiciário, n. 1, 1976.

ROCHA, Arthur Pinto da. Primeiro jury antigo. Dissertações (Direito Público), organizadas por Manoel Álvaro de Souza Sá Vianna, por ocasião do Congresso Jurídico Americano, comemorativo do 4ำ centenário do descobrimento do Brasil. v. 2 Rio de Janeiro: Imprensa Nacional, 1904.

SILVA, Germano Marques da. Curso de Processo Penal. Lisboa: Verbo, 1994. v. 1.

TUCCI, Rogério Lauria. Lineamentos do processo penal romano. São Paulo: Edusp/ Bushatsky, 1976.

. Tribunal do Júri - Estudo sobre a mais democrática instituição jurídica brasileira. São Paulo: Editora Revista dos Tribunais, 1999.

WHITACKER, Firmino. O Júri. 6. ed. São Paulo: Livraria Acadêmica/Saraiva, 1930. 